\title{
ВПЛИВ СИСТЕМИ ОХОЛОДЖЕННЯ НА КОНСТРУКТИВНІ ПОКАЗНИКИ СТАТИЧНИХ ПЕРЕТВОРЮВАЧІВ
}

Д-р техн. наук А.М. Муха (ДНУЗТ)

\section{ВЛИЯНИЕ СИСТЕМЫ ОХЛАЖДЕНИЯ НА КОНСТРУКТИВНЫЕ ПОКАЗАТЕЛИ СТАТИЧЕСКИХ ПРЕОБРАЗОВАТЕЛЕЙ}

\author{
Д-р техн. наук А.Н. Муха (ДНУЖТ)
}

\section{THE INFLUENCE OF THE COOLING SYSTEM ONTO DESIGN PARAMETERS OF STATIC CONVERTERS}

\author{
Dr. techn. sciences A. Mukha (DNUZT)
}

Досліджено питання впливу виду системи охолодження на конструктивні показники статичних перетворювачів для електрорухомого складу залізниць.

Ключові слова: частота, втрати, перетворювач, охолодження.

Исследован вопрос влияния вида системы охлаждения на конструктивные показатели статических преобразователей для электроподвижного состава железных дорог.

Ключевые слова: частота, потери, преобразователь, охлаждение.

The widespread introduction of modern power semiconductor element base let significantly reduce the size of the traction converters, but the problem arises more efficient selection of thermal power losses in the individual switches, which can lead to an increase in size of the converters. The author investigated the question of the influence of the form of the cooling system onto design parameters of static converters for electric rolling stock of railways. Author's researches are showed that the use of liquid cooling makes it possible, in comparison with forced air cooling, to reduce by $7 \ldots 8 \%$ overall traction performance of static converters.

Keywords: frequency, loses, converter, cooling.

Вступ. Долі електрифікованих постійним та змінним струмом залізниць України є майже однаковими. На станціях стикування працюють так звані двосистемні електровози ВЛ82, які розроблені та виготовлені ще при СРСР. Тому необхідність забезпечення процесу перевезень на електрифікованих залізницях незалежно від роду струму та значення напруги у контактній мережі без заміни електровозів на станціях стикування вимагає використання тягового електрорухомого складу, який може працювати як при постійному так i змінному струмах при різних рівнях напруги у контактній мережі. Такий тяговий електрорухомий склад називаємо багатосистемним.

Створення багатосистемних електровозів стало можливим завдяки успіхам силової напівпровідникової техніки - появі повністю керованих вентилів, підвищенню класу приладів та їх робочих струмів.

Поява нової елементної бази призвела до удосконалення існуючих та створення нових схемних та конструктивних рішень для перетворювачів. Провідними фірмамивиробниками статичних перетворювачів 
зокрема були створені загальнопромислові приводи 3 двигунами постійного та змінного струмів та перетворювачі іншого функціонального призначення.

Безумовно, такі зміни не обминули i тягові статичні перетворювачі, які живлять тягові двигуни електровозів та електропоїздів.

Але ж питання визначення взаємного зв'язку між потужністю тягового привода масогабаритними показниками статичного перетворювача та його системи охолодження, що $\epsilon$ невід'ємною його частиною, не порушувалось.

Основні структури i схемотехнічні рішення для традиційного електрорухомого складу (ЕРС) досить повно подані у літературі [1, 2, 3, 4 та ін.].

Мета роботи. Провести аналіз промислових показників перетворювачів для розробки рекомендацій щодо раціональних конструктивних показників перетворювачів тягового електропривода.
Матеріал і результати досліджень. Узагальненою характеристикою конструктивних показників статичних перетворювачів приймаємо питомий об'єм, який визначаємо так: $V_{P}=\frac{V}{P}, \mathrm{~m}^{3} / \mathrm{\kappa} \mathrm{B}$, де $V$ - об'єм статичного перетворювача, ${ }^{3} ; P$ - потужність перетворювача, кВт [5].

Вихідними даними $є$ : потужність, габарити, елементна база та вид охолодження напівпровідникових ключів існуючих перетворювачів.

Подані надалі залежності питомого об'єму від потужності перетворювачів $V_{P}=f(P)$ враховують тип елементної бази, вид охолодження.

На рис. 1 подана залежність $V_{P}=f(P)$ побудована за експериментальними даними для перетворювачів ВАТ «Запорізький завод «Преобразователь»» (елементна база - тиристор, охолодження примусове повітряне) з діапазоном робочих напруг до одного кіловата.

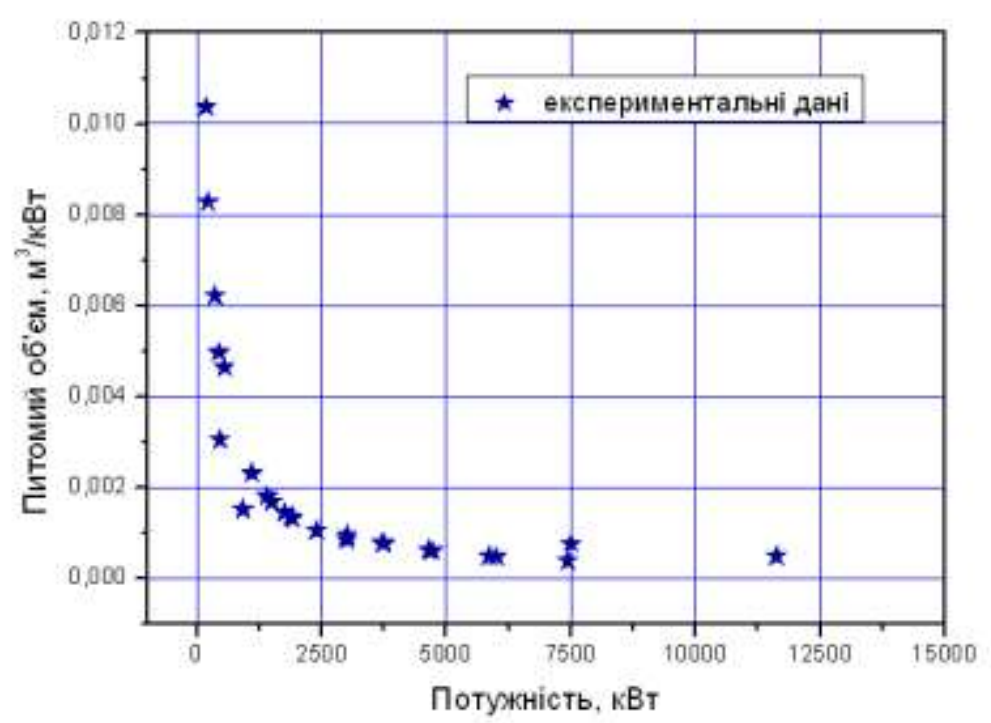

Рис. 1. Залежність питомого об’єму перетворювачів ВАТ «Запорізький завод «Преобразователь»» (елементна база - тиристор, охолодження - примусове повітряне) 3 діапазоном робочих напруг до одного кіловата від потужності перетворювачів

Для отримання аналітичних залежностей для питомого об'єму від їх потужності проведемо апроксимацію експериментальних значень (рис. 2). 


\begin{tabular}{|c|c|}
\hline Залежність & питомого \\
\hline перетворювачів & потужності \\
\hline апроксимувалась & за допомогою таких \\
\hline
\end{tabular}

$$
y(x)=y_{0}+A_{1} e^{\left(-\frac{x}{t_{1}}\right)}+A_{2} e^{\left(-\frac{x}{t_{2}}\right)}
$$

(експоненціальна другого порядку).

При цьому коефіцієнти апроксимації мають такі значення: $y_{0}=0, A_{1}=0,00223$, $t_{1}=3942,92663, \quad A_{2}=0,01657$, $t_{2}=239,70193$.

Тоді вираз для апроксимованої залежності $V_{P}=f(P)$ має вигляд

$$
\begin{aligned}
V_{\mathrm{P}}(P) & =0+0,00223 \cdot e^{\left(-\frac{P}{3942.92663}\right)}+ \\
& +0,01657 \cdot e^{\left(-\frac{P}{239.70193}\right)}
\end{aligned}
$$

Отримані залежності дозволяють у першому наближенні оцінити вплив системи охолодження перетворювача на його габаритні розміри, для цього подамо апроксимовані залежності 3 рис. 2 та 3 в одній системі координат (рис. 4).

Аналіз поданих на рис. 4 залежностей та використання отриманих коефіцієнтів апроксимації, дозволяє порівняти, у відсотках, виграш від використання водяного охолодження в перетворювачах, які живлять двигуни постійного струму.

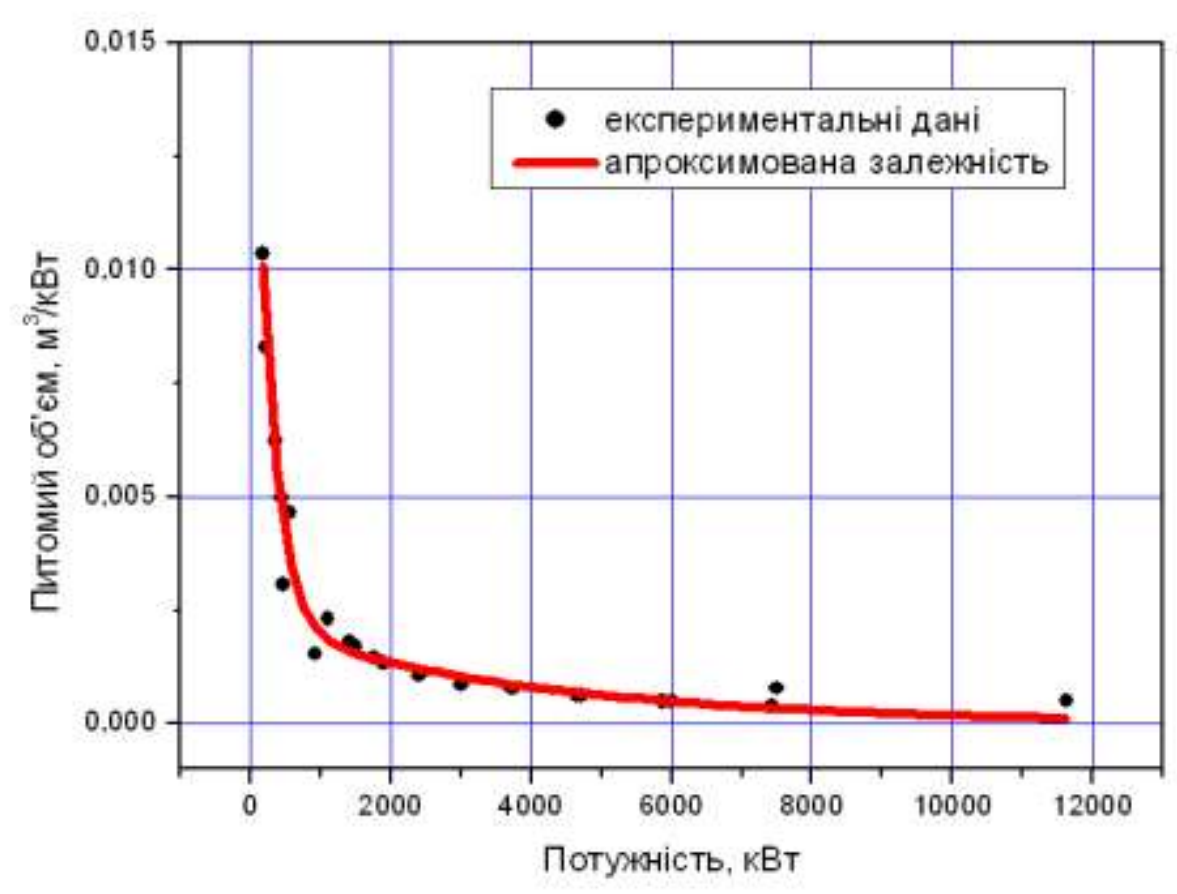

Рис. 2. Результати апроксимації залежності питомого об’єму перетворювачів ВАТ «Запорізький завод «Преобразователь»» (елементна база - тиристор, охолодження примусове повітряне) з діапазоном робочих напруг до одного кіловата від потужності перетворювачів 


\section{Електричний транспорт}

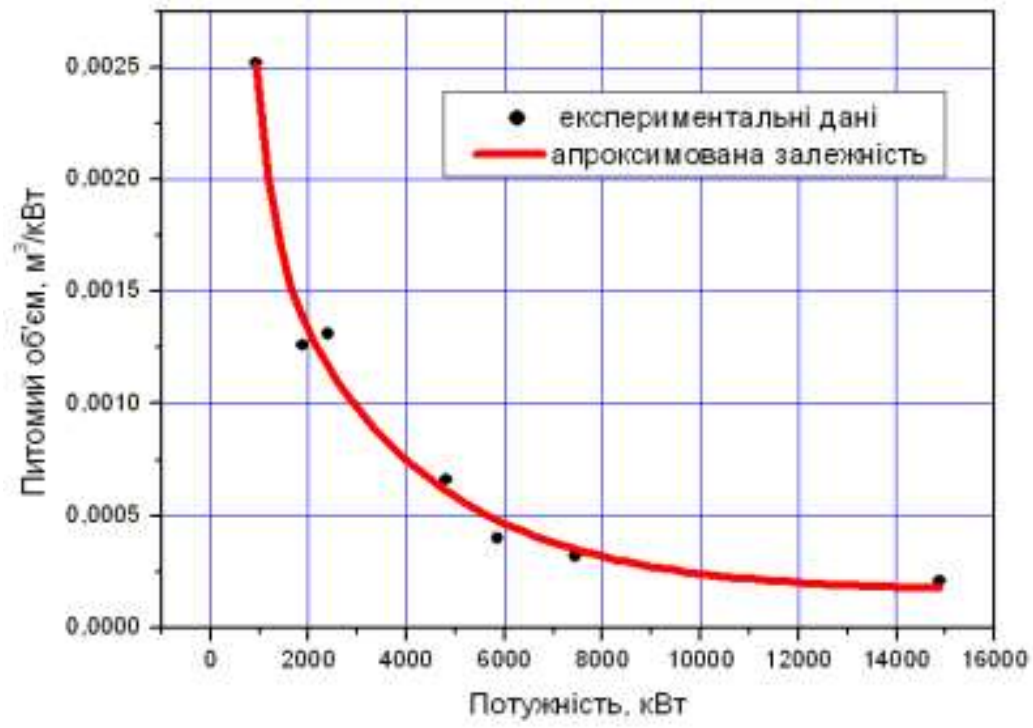

Рис. 3. Результати апроксимації залежності питомого об’єму перетворювачів ВАТ «Запорізький завод «Преобразователь»» (елементна база - тиристор, охолодження - водяне) 3 діапазоном робочих напруг до одного кіловата від потужності перетворювачів

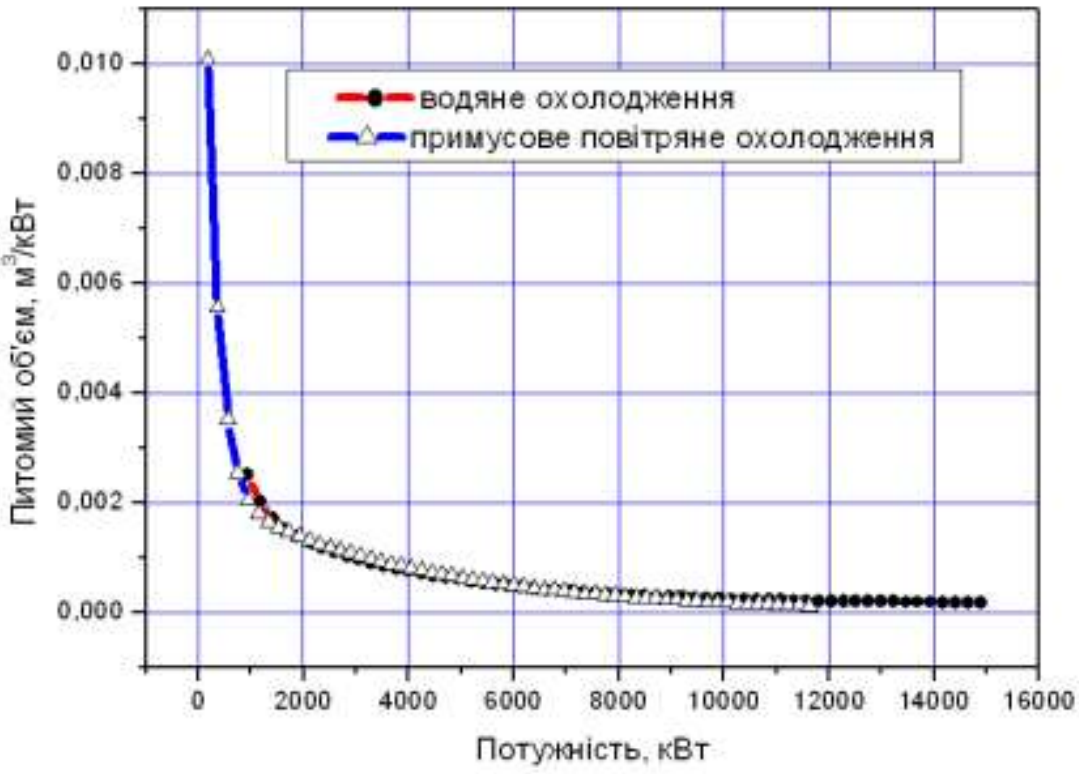

Рис. 4. Вплив виду охолодження на габаритні розміри перетворювачів ВАТ «Запорізький завод «Преобразователь»» (елементна база - тиристор) з діапазоном робочих напруг до одного кіловата

Проведені автором дослідження дозволили встановити, що використання водяного (рідинного) охолодження для перетворювачів потужністю 4000 кВт дозволяє виграти приблизно $7,4 \%$ від загального об’єму перетворювача у порівнянні 3 таким самим за потужністю перетворювачем, який побудовано 3 використанням примусового повітряного охолодження. 
Подамо цей розрахунок.

Питомий об'єм перетворювача потужністю 4000 кВт на базі тиристорів 3 примусовим охолодженням дорівнює

$$
\begin{aligned}
& V_{\text {РПП }}(4000)=0+0,00223 \cdot e^{\left(-\frac{4000}{394292663}\right)}+ \\
& +0,01657 \cdot e^{\left(-\frac{4000}{239,70193}\right)}=8,086 \cdot 10^{-4}\left[\mathrm{M}^{3} / \mathrm{KBT}\right]
\end{aligned}
$$

Питомий об'єм перетворювача потужністю 4000 кВт на базі тиристорів 3 водяним охолодженням дорівнює

$$
\begin{aligned}
& V_{\text {РBBo }}(4000)=0,000158+0,01263 \cdot e^{\left(-\frac{4000}{331,4823}\right)}+ \\
& +0,00218 \cdot e^{\left(-\frac{4000}{3063,27429}\right)}=7,488 \cdot 10^{-4}\left[\mathrm{~m}^{3} / \mathrm{kBT}\right]
\end{aligned}
$$

Приймаючі показники системи 3 примусовим повітряним охолодженням за $100 \%$ отримаємо таку відносну зміну питомого об'єму перетворювача:

$$
\begin{aligned}
& \Delta V_{\mathrm{P}}=\frac{V_{\text {PIII }}-V_{\text {PBBo }}}{V_{\text {РाII }}} \cdot 100 \%= \\
& =\frac{8,086 \cdot 10^{-4}-7,488 \cdot 10^{-4}}{8,086 \cdot 10^{-4}} \cdot 100 \%=7,39 \%
\end{aligned}
$$

Висновки. Дослідження, проведені автором, дозволили встановити, що використання рідинного охолодження у порівняні 3 повітряним примусовим зменшує приблизно на $7 \ldots 8$ \% габаритні показники тягових статичних перетворювачів.

\section{Список використаних джерел}

1. Захарченко, Д.Д. Тяговые электрические машины [Текст]: учеб. для вузов ж.-д трансп. / Д.Д. Захарченко, Н.А. Романов. - М.: Транспорт, 1991. - 343 с.

2. Калинин, В.К. Электровозы и электропоезда. [Текст] / В.К. Калинин. - М.: Транспорт, 1991. - 480 с.

3. Безрученко, В.М. Тягові електричні машини електрорухомого складу [Текст]: навч. посібник. / В.М. Безрученко, В.К. Марченко. В.В. Чумак. - Дніпропетровськ: Вид-во Дніпропетровського нац. ун-ту залізнич. тр-ту ім. акад. В. Лазаряна, 2003. - 252 с.

4. Преобразовательные устройства электропоездов с асинхронными тяговыми двигателями. [Текст] / А.М. Солодунов, Ю.М. Иньков, Г.Н. Коваливкер, В.В. Литовченко; под ред. А.М. Солодунова. - Рига: Зинантне, 1991. - 351 с.

5. Зиновьев, Г.С. Основы силовой электроники [Текст]: учебник. - Новосибирск: Издво НГТУ, 1999. - Ч. 1. - 199 с.

Муха Андрій Миколайович, д-р техн. наук, кафедра електротехніки та електромеханіки, Дніпропетровський національний університет залізничного транспорту ім. акад. В. Лазаряна.

Mukha A., dr. techn. sciences, department of Electrical engineering and electromechanics. 